\title{
IN VITRO COMPARISON OF THE ANTIBACTERIAL ACTIVITY OF ETHANOLIC EXTRACT OF AZADIRACHTA INDICA LEAVES WITH GENTAMYCIN, AMPICILLIN, NITROFURANTOIN, AND COTRIMOXAZOLE ON BACTERIAL PATHOGENS ISOLATED FROM URINARY TRACT INFECTION PATIENTS
}

\author{
MEENAKSHI JINDAL ${ }^{1 *}$, CHAUHAN S ${ }^{2}$ \\ ${ }^{1}$ Department of Pharmacology, Muzaffarnagar Medical College, Muzaffarnagar, Uttar Pradesh, India. ${ }^{2}$ Department of Microbiology, \\ Muzaffarnagar Medical College, Muzaffarnagar, Uttar Pradesh, India. Email: drmeenakshijindal@rediffmail.com
}

Received: 18 March 2017, Revised and Accepted: 22 April 2017

\section{ABSTRACT}

Objective: In vitro comparison of the antibacterial activity of ethanolic extract of Azadirachta indica (neem) leaves with gentamycin, ampicillin, nitrofurantoin, and cotrimoxazole in bacterial pathogens isolated from urinary tract infection (UTI) patients.

Methods: Ethanolic extract of neem leaves was prepared by the standard method. The antimicrobial activity against bacteria isolated from UTI patients was determined by agar well diffusion method and then mean zone of inhibition of neem extract was compared with a mean zone of inhibition of gentamycin, ampicillin, nitrofurantoin, and cotrimoxazole.

Results: Among 200 samples which were included in the study, bacteria isolated were Escherichia coli (60\%), Klebsiella pneumoniae (15\%), Pseudomonas aeruginosa (11\%), Enterococcus faecalis (5\%), Proteus mirabilis (3\%), and Staphylococcus aureus (6\%). The result obtained was statistically analyzed by unpaired t-test. The difference in the mean diameter of the zone of inhibition between ethanolic extract of Azadirachta indica (neem) leaves and nitrofurantoin was statistically highly significant for K. pneumoniae $(\mathrm{p}<0.0001)$ and $P$. mirabilis ( $\mathrm{p}=0.01)$ and insignificant for other bacteria. On comparing, the mean diameter of the zone of inhibition of ethanolic extract of $A$. indica (neem) leaves with ampicillin and cotrimoxazole, it was found to be statistically highly significant for all bacteria E. coli $(\mathrm{p}<0.0001)$, K. pneumoniae $(\mathrm{p}<0.0001)$, P. aeruginosa (p<0.0001) E. faecalis $(\mathrm{p}<0.001)$, and $S$. aureus $(\mathrm{p}<0.0001)$ expect $P$. mirabilis. The mean diameter of the zone of inhibition of ethanolic extract of $A$. indica (neem) leaves when compared with gentamycin was statistically highly significant for all the bacteria.

Conclusion: The ethanolic extract of $A$. indica leaves has antibacterial activity. Antibacterial activity of ethanolic extract of $A$. indica leaves is comparable to nitrofurantoin for bacteria E. coli, P. aeruginosa, E. faecalis, and S. aureus. Ethanolic extract of $A$. indica leaves has similar antibacterial activity as ampicillin and cotrimoxazole for bacteria $P$. mirabilis. The antibacterial activity of gentamycin is less as compared to an ethanolic extract of $A$. indica leaves for all the bacteria.

Keywords: Urinary tract infection, Azadirachta indica, Antibacterial activity.

(C) 2017 The Authors. Published by Innovare Academic Sciences Pvt Ltd. This is an open access article under the CC BY license (http://creativecommons. org/licenses/by/4. 0/) DOI: http://dx.doi.org/10.22159/ajpcr.2017.v10i8.18557

\section{INTRODUCTION}

Medicinal plants and herbal medicines are part and parcel of human society to combat both infectious and non-infectious diseases. Azadirachta indica is well known in India and other countries for more than 2000 years for its medicinal values [1]. A. indica belongs to the botanic family Meliaceae, commonly known as neem. The Sanskrit name of neem is Arishtha meaning reliever of sicknesses. All parts of neem plant such as leaves, bark, flower, fruit, seed, and root have advantages in medical treatment. It exhibits antibacterial, antifungal, and antiviral activities [1]. It exhibits pharmacological activities such as antioxidant, antimalarial, anticarcinogenic, anti-inflammatory, antiulcer, antimutagenic, antihyperglycemic, and anti-diabetic properties [2].

A urinary tract infection (UTI) is a bacterial infection and is a most common hospital-acquired infection, UTI has become the most common hospital-acquired infection accounting for as many as 35\% of nosocomial infections, and they are the second most common cause of bacteremia in hospitalized patients [3]. The most common cause of UTI is Gram-negative bacteria that belong to the family Enterobacteriaceae. Members of this family include Escherichia coli, Klebsiella, Enterobacter, and Proteus. Furthermore, Gram-positive Staphylococcus species plays a role in the infection [4]. In the past three decades, there have been a lot of reports in the scientific literature on the inappropriate use of antimicrobial agents and the spread of bacterial resistance among microorganisms causing UTI [5]. Keeping in view the growing problem with UTIs and drug resistance, this study was undertaken with an objective to find more efficient antibacterial agents of plant origin with less side-effect.

\section{METHODS}

Collection of raw material

The A. indica (neem) leaves were collected from Forest Research Institute, Dehradun and authenticated by Senior Scientist Dr. Rashmi.

\section{Preparation of ethanolic extract of the $\boldsymbol{A}$. indica}

Fresh leaves of neem ( $A$. indica) were collected locally and were air dried in the shade. The $A$. indica leaves extract was then prepared by grounding $50 \mathrm{~g}$ of leaves using mortar and pestle, and the yield was successively soaked by $80 \%$ ethanol for about $72 \mathrm{hrs}$, with daily filtration and evaporation. Solvents were evaporated under reduced pressure to dryness using rotary evaporator apparatus. Extracts were exposed to air till complete dryness [6].

\section{Study population}

- Inclusion criteria - 200 UTI patients having significant bacteria with single organism were included in the study 
- Exclusion criteria - Patients with multiple organisms were excluded in the study.

The study was conducted in the Muzaffarnagar Medical College. All urine samples were streaked on cysteine lactose electrolyte deficient medium. After overnight incubation at $37^{\circ} \mathrm{C}$ organism was identified on the basis of standard biochemical tests [7].

\section{Antibacterial susceptibility assay}

The antibacterial activity of the neem ethanolic extracts was carried out using the agar well diffusion method [8]. Lawn culture of the test organism adjusted to $0.5 \mathrm{McF}$ arland turbidity. Standard was made on the Mueller-Hinton agar plates using sterile cotton swabs. A sterile cork borer was then used to make well (6 $\mathrm{mm}$ diameter) for the ethanolic extract of neem. $100 \mu \mathrm{l}$ of the extract was introduced into the well with the help of micropipettes. The culture plates were allowed to stand on the working bench for 30 minutes for pre-diffusion and were then incubated in an upright position at $37^{\circ} \mathrm{C}$ for $24 \mathrm{hrs}$. After $24 \mathrm{hrs}$ antibacterial activity was determined by measurement of the mean diameter of zones of inhibition (mm). Standard antibiotic disc of nitrofurantoin $(300 \mathrm{mcg} / \mathrm{disc})$, ampicillin $(10 \mathrm{mcg} / \mathrm{disc})$, gentamycin (10 mcg/disc), and cotrimoxazole $(25 \mathrm{mcg} / \mathrm{disc})$ was used as positive control. All the tests were done in triplicate to minimize the test error. The study was performed in under strict aseptic conditions to ensure consistency of all findings.

Mean zones of inhibition of ethanolic extract and various antibiotics were calculated and tabulated in Table 1.

\section{RESULTS}

Among 200 samples which were included in the study, bacteria isolated were E. coli (60\%), Klebsiella pneumoniae (15\%), Pseudomonas aeruginosa (11\%), Enterococcus faecalis (5\%), P. mirabilis (3\%), and Staphylococcus aureus (6\%) as shown in Table 2.

\section{Data analysis}

The data obtained were analyzed statistically by applying unpaired t-test by SPSS version 19 . The data were expressed in mean \pm 2 standard deviation.

The difference in the mean diameter of the zone of inhibition between ethanolic extract of $A$. indica (neem) leaves and nitrofurantoin was highly significant for $K$. pneumoniae $(\mathrm{p}<0.0001)$ and P. mirabilis $(\mathrm{p}=0.01)$ but was insignificant for $E$. coli $(\mathrm{p}=0.07)$, . aeruginosa $(\mathrm{p}=0.8)$, E. faecalis $(\mathrm{p}=0.37)$, and $S$. aureus $(\mathrm{p}=0.18)$ (Table 1$)$. Hence, this shows that ethanolic extract of $A$. indica (neem) leaves and nitrofurantoin antibacterial activity is almost similar for bacteria E. coli, P. aeruginosa, E. faecalis, and S. aureus.

On comparing the mean diameter of the zone of inhibition of ethanolic extract of $A$. indica (neem) leaves with ampicillin, it was found to be statistically highly significant for all bacteria E. coli $(\mathrm{p}<0.0001)$, $K$. pneumoniae $(\mathrm{p}<0.0001)$, P. aeruginosa $(\mathrm{p}<0.0001)$, E. faecalis $(\mathrm{p}<0.001)$, and $S$. aureus $(\mathrm{p}<0.0001)$ expect P. mirabilis $(\mathrm{p}=0.21)$ (Table 1).

Similar result was for cotrimoxazole it was insignificant for $P$. mirabilis $(\mathrm{p}=0.37)$. It was highly significant for $E$. coli $(\mathrm{p}<0.0001)$, K. pneumoniae $(\mathrm{p}<0.0001)$, P. aeruginosa $(\mathrm{p}<0.0001)$, E. faecalis $(\mathrm{p}<0.001)$, and $S$. aureus $(\mathrm{p}<0.0001)$ (Table 1). Hence, we can predict that ethanolic extract of $A$. indica (neem) leaves ampicillin, cotrimoxazole antibacterial activity is almost comparable for bacteria P. mirabilis.

The mean diameter of the zone of inhibition of ethanolic extract of $A$. indica (neem) leaves when compared with gentamycin was statistically highly significant for all the bacteria. E. coli $(\mathrm{p}<0.0001)$, $K$. pneumoniae $(\mathrm{p}<0.0001), P$. aeruginosa $(\mathrm{p}<0.0001)$, E. faecalis $(\mathrm{p}<0.001)$, P. mirabilis $(\mathrm{p}<0.0001)$, and S. aureus $(\mathrm{p}<0.0001)$ (Table 1$)$. This shows that antibacterial activity of the ethanolic extract of $A$. indica (neem) leaves is not similar to gentamycin for all bacteria. Antibacterial activity of ethanolic extract of $A$. indica (neem) leaves was higher to gentamycin.

\section{DISCUSSION}

UTI is a complicated problem that continues to present new challenges due to change in the etiology of UTI and the antimicrobial resistance of urinary pathogens over the years. Factors such as the changing in patient population and extensive use and abuse of antimicrobial agents could contribute to changes in the microbial profile of urinary tract isolates [9]. Many of the existing synthetic drugs cause various side effects. Hence, development of plant-based compounds is required to meet this demand for production of newer drugs with minimal side effects. In this study, we have shown that ethanolic extracts of A. indica (neem) leaves to exhibit high antibacterial activity against all tested bacterial strains. It may be because of the presence of bioactive compounds (alkaloids, flavonoids, essential oils, terpenoids, tannins, etc.), which may be enhanced in the presence of ethanol; and stronger extraction capacity of ethanol may have yielded a greater number of active constituents responsible for antibacterial activity thus rationalizing the use of $A$. indica leaves in primary health care [10]. Subapriya and Nagini reported that the presence of high concentrations of azadirachtin, quercetin, and $\beta$-sitosterol in $A$. indica leaves might be responsible for strong antibacterial and antifungal activity [11]. Our study concise with the Raja et al. who compared the antimicrobial efficacy of aqueous extracts of leaf of $A$. indica against human pathogenic bacteria (S. aureus, E. faecalis, and P. aeruginosa). They found that leaf extract exhibited strong antibacterial activity against these bacteria [12]. Through phytochemical and biological experiments the antibacterial effect of $A$. indica leaves was also confirmed by Pandey et al. [13]. Hence, antimicrobial properties of plant extracts and their possible use in pharmaceutical industries for the development of newer and safer drugs should be encouraged [14].

Table 1: In vitro comparison of antibacterial activity of ethanolic extract of $A$. indica (neem) with other standard antibiotics

\begin{tabular}{|c|c|c|c|c|c|c|}
\hline \multirow[t]{3}{*}{ Extract/antibiotic } & \multicolumn{6}{|c|}{ Mean diameter of zone of inhibition (mm) } \\
\hline & \multicolumn{6}{|l|}{ Mean $\pm 2 S D$} \\
\hline & Escherichia coli & $\begin{array}{l}\text { Klebsiella } \\
\text { pneumoniae }\end{array}$ & $\begin{array}{l}\text { Pseudomonas } \\
\text { aeruginosa }\end{array}$ & $\begin{array}{l}\text { Enterococcus } \\
\text { faecalis }\end{array}$ & $\begin{array}{l}\text { Proteus } \\
\text { mirabilis }\end{array}$ & Staphylococcus aureus \\
\hline $\begin{array}{l}\text { Ethanol extract of } \\
\text { neem }\end{array}$ & $24.90 \pm 10.04$ & $15.10 \pm 3.46$ & $20.34 \pm 0.92$ & $19.50 \pm 6.32$ & $14.00 \pm 0.14$ & $20.10 \pm 6.22$ \\
\hline Nitrofurantoin & $25.86 \pm 6.08$ & $22.30 \pm 1.00^{* * *}$ & $20.31 \pm 0.96$ & $18.00 \pm 8.42$ & $18.50 \pm 7.66^{*}$ & $21.50 \pm 3.46$ \\
\hline Gentamycin & $13.00 \pm 4.60^{* * *}$ & $12.06 \pm 3.22^{* * *}$ & $10.40 \pm 6.96^{* * *}$ & $12.60 \pm 1.68^{* * *}$ & $10.11 \pm 2.18^{* * *}$ & $10.00 \pm 3.60^{* * *}$ \\
\hline Cotrimoxazole & $11.16 \pm 6.92^{* * *}$ & $10.46 \pm 0.82^{* * *}$ & $13.20 \pm 5.04^{* * *}$ & $14.30 \pm 5.48^{* *}$ & $14.11 \pm 0.56$ & $09.50 \pm 3.46^{* * *}$ \\
\hline
\end{tabular}

Comparison of the mean diameter of the zone of inhibition of ethanolic extract of $A$. indica with other standard antibiotics. Signifies statistical significant in antibacterial activities between ethanolic extract of $A$. indica leaves and other standard drugs. $\mathrm{p}>0.05$ (insignificant), $\mathrm{p}<0.05$ (significant), ${ }^{*} \mathrm{p}<0.01$ or $* * \mathrm{p}<0.001$ or ${ }^{* * *} \mathrm{p}<0.0001$ (highly significant). A. indica: Azadirachta indica, SD: Standard deviation 
Table 2: Bacteria isolated from urine culture

\begin{tabular}{lll}
\hline S.No. & Bacteria isolated & n (\%) \\
\hline 1 & Escherichia coli & $120(60)$ \\
2 & Klebsiella pneumoniae & $30(15)$ \\
3 & Pseudomonas aeruginosa & $22(11)$ \\
4 & Enterococcus faecalis & $10(5)$ \\
5 & Proteus mirabilis & $6(3)$ \\
6 & Staphylococcus aureus & $12(6)$ \\
\hline
\end{tabular}

\section{CONCLUSION}

The ethanolic extract of $A$. indica leaves has antibacterial activity. Antibacterial activity of ethanolic extract of $A$. indica leaves is comparable to nitrofurantoin for bacteria E. coli, P. aeruginosa, E. faecalis, and $S$. aureus. The antibacterial activity of ethanolic extract A. indica leaves is also comparable to ampicillin and cotrimoxazole for bacteria P. mirabilis. Antibacterial activity of gentamycin is less as compared to ethanolic extract of $A$. indica leaves for all the bacteria.

\section{REFERENCES}

1. Biswas K, Ishita C, Ranajit KB, Uday B. Biological activities and medicinal properties of neem (Azadirachta indica). Curr Sci 2002;82:1336-45.

2. Orhue PO, Momoh AR, Igumbor EO. Antibacterial effect of Azadirachta indica parts on some urinary tract bacterial isolates. Asian J Plant Sci Res 2014;4(2):64-7.
3. Stamm WE, Norrby SR. Urinary tract infections: Disease panorama and challenges. J Infect Dis 2001;183 Suppl 1:S1-4.

4. Kunin CM. Urinary tract infections in females. Clin Infect Dis 1994;18:1-12.

5. Tenover FC, McGowan JE Jr. Reasons for the emergence of antibiotic resistance. Am J Med Sci 1996;311(1):9-16.

6. Hala A, Mohammed AI, Fadhil A. Omer antibacterial activity of Azadirachta indica (Neem) leaf extract against bacterial pathogens in Sudan. Am J Res Commun 2015;3(5):246-51.

7. Koneman EW, Allen SD, Janda WM, Schreckenberger PC, Winn WC. Color Atlas and Text Book of Diagnostic Microbiology. $5^{\text {th }}$ ed. Philadelphia, PA: Lippincott-Raven Publishers; 1997. p. 893-952.

8. Perez C, Pauli M, Barzerque P. An antibiotic assay by agar-well diffusion method. Acta Biol Med Exp 1990;15:113-5.

9. Mady S, Helmi H. Urinary tract infection pathogens and antibiotic sensitivity patterns in hospitalized infants and children in Al-Jahra Hospital, Kuwait. Egypt J Med Microbiol 2003;12:415-20.

10. Gosh A, Das BK, Roy A, Mandal B, Chand G. Antibacterial activity of some medicinal plant extracts. J Nat Med 2008;62:259-62.

11. Subapriya R, Nagini S. Medicinal properties of neem leaves: A review. Curr Med Chem Anticancer Agents 2005;5(2):149-6.

12. Raja Y, Krishna C, Lokanatha O, Mamatha S, Damodar C. Antimicrobial activity of Azadirachta indica (neem) leaf, bark and seed extracts. Staphylococcus aureus. Int J Res Phytochem Pharmacol 2013;3(1):1-4.

13. Pandey G, Verma K, Singh M. Evaluation of phytochemical, antibacterial and free radical scavenging properties of Azadirachta indica [neem leaves]. Int J Pharm Pharm Sci 2014;6(2):444-7.

14. Paluri V, Chandran SR, Kumar G, Karthik L, Rao KV. Phytochemical composition and in vitro antimicrobial activity of methanolic extract of Callistemon lanceolatus D.C. Int J Pharm Pharm Sci 2012;4(2):699-702. 